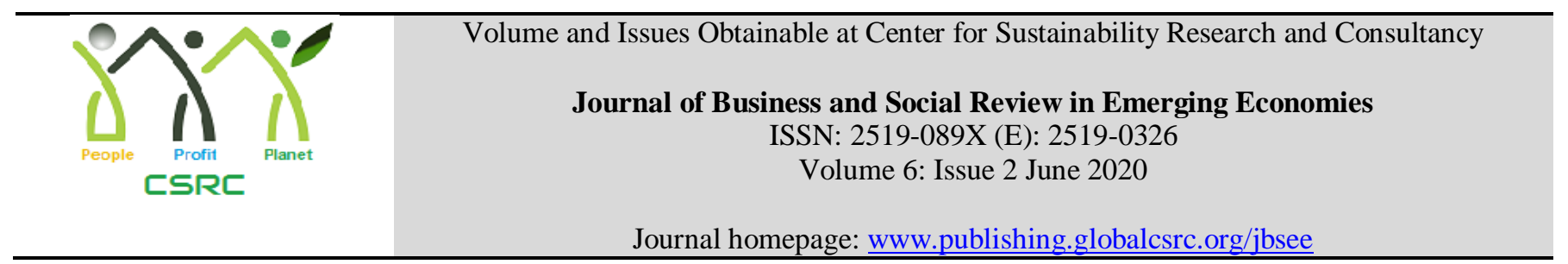

\title{
Growth and Development of Saraiki Novel
}

\author{
${ }^{1}$ Syed Safdar Hussain, ${ }^{2}$ Ayaz Ahmad Rind
}

${ }^{1}$ Assoc. Professor, Department of Saraiki, The Islamia University of Bahawalpur Pakistan, ssafdar.iub@gmail.com ${ }^{2} \mathrm{PhD}$ Scholar, Department of Saraiki, The Islamia University of Bahawalpur Pakistan, ayazahmad412@gmail.com

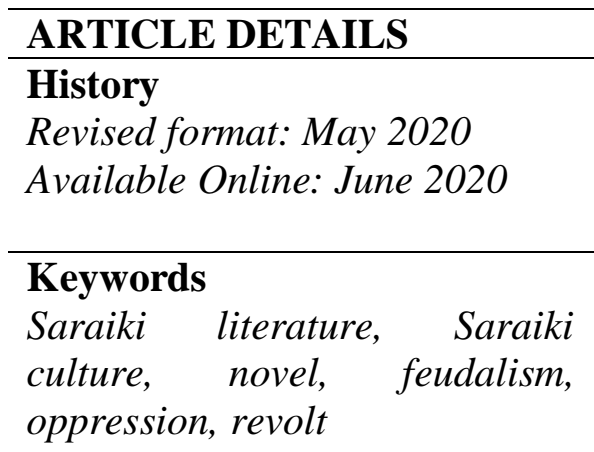

JEL Classification

$M 0, M 1$

\begin{abstract}
The linguistic developments have always been coincideing with the development of human civilizations. It is, therefore, commonly believed among historians and linguistic scholars that language and its various generes are the museum of any civilization that help understand depth and breadth of its development over time. The historical development of Saraiki language over time also has been reflected into its various geners such as poetry, drama, prose, folklores or nonfiction, and media. The present study has examined the the historical development of literary genre, novel in modern Saraiki literature and its sociocultural and linguistic implications. The study would help researcg scholars in the area of Saraiki literature and linguistics to gain deeper understanding of historical development of Saraiki novel in relation to other generes and look into its relationship with sociocultural development of people in Saraiki speaking areas.
\end{abstract}

\section{OPEN ACCESS}

(C) 2020 The authors, under a Creative Commons AttributionNonCommercial 4.0

Corresponding author's email address: ssafdar.iub@gmail.com

Recommended citation: Hussain, S. S., and Rind, A. A. (2020). Growth and Development of Saraiki Novel. Journal of Business and Social Review in Emerging Economies, 6(2), 893-904

\section{Introduction}

It is the natural instinct of man that he is inquisitive to move ahead during this struggle, there comes change with the passage of time and he moves forward by making progress. Not only he makes progress but also his ways of living life and culture are altogether progressed. Although this progress has same side effects for man's culture and civilization and these things have brought chaos and unrest in human life but there we see even no meager change in the interest of story. Like the other parts and countries of the world and language of the world the story has reached to us after passing through Folk Tale and Dastan. If we look at it with careful consideration, we come to know that novel has been structured and founded on the basis of Folk Tale and Dastan in Saraiki language and literature.

\subsection{Development of Saraiki Novel in Relation to that in Other Notable Languages}

Dilshad kalanchvi says:

"novel nwin shai kon akhendy ty ay drasl dastanen da nwan roop hy'. (Kalanchvi, 1987, p.227) 
In this way we come to know that infact an old tale has been clothed a new dress. When man steped forward into a civilized world some other realaties of life were reveled to him which were carriying problems bitterness and even happiness in it. There was peace and blessing of life pain, pleasure and there was struggle as well so these effects can be seen on human life and this has brought a drastic change in human culture and way of life. This has also affected story and folk tale simultaneously which further was transformed into Dastan and moving forward it took from of novel. In that way it passed from phase of imagination and fantasy to the real world of human being and appeared in the form of modern genre which was named as novel.

The best subject matter of man's study is his own life.

According to Dr. Nazeer Ahmad:

"jo duniya ky halat per kbhi ghour nhi ktta is sy ziyada koi bywaqof nhi hy. aur ghour krny ky wasty dunyan main hazaron trha ki batain hain laiken sb sy umda aur zarori aadmi ka hal hy". (Hussaini, 1990, p.15)

That's why it is said that no aspect of life can be left untouched from the pen of novelist. It is such a long genre of literature that highlights different aspects of human life. It's a long long tale in which matters realated to man and society are discussed at the same time through life living chractors. It's a new form of folk tale and legend that's why it is called novel. Dilshad Kalanchvi says about this.

"Adab main yeh nai shai is liyy kehlaya keh yeh dastanon ka nya roop hy". (Kalancvi, 1982, p.135)

According to Dr. Ahsan Farooqi:

"navel aty dastan dy ajzai turkebi wich furq kaini sirf zamany ty insani shaoor di trqi dy nal nal oondi asliat budil gai hy”. (Hussaini, 1951, p.10)

In 'Qissa' there_are supernatural elements like fairies, demons, giants and other mysterious non-human craeaturs but when we discuss novel we don't see any such elements in it. Dastan's are lengthy accounts of events in which bravery, fights, wars and mythical and fictional events or stories are described but contrary to it in novel life living characters and human social problems are highlighted. The word novel is derived from Latin which means new.

In this connection Ali Abbas Hussaini writes:

"Lufz nawel lateni toon fransesi zuban wichon thenda hoya angrezi wich aty angrizi ton asady adub wich muntuqil thai. Angrezi wich ay aam tour ty nwan dy maani wich istemal keta wendy'. (Lashari, 2018, p.6)

Yet another writer of Urdu Dr. Sohail Bukhari also says.

“ay lufz nawel lateni ton fransesi aty angrezi wul angrezi ton asady adub wich muntaqil thai”. (Durrani, 2008, p.14)

According to Hafeez ul Rehman Hafeez:

"Nusri adub di sinfan wichon nawel hik aynjhi sinf hy jendy wich zindgi apnry sary rungan nal jhal dikhendi hy". (Hafeez, 2009, p.21)

Novel is the perfect form of art. No other genre of literature allows freedom of expression as novel does. The best creative abilities of novelist can be compared to a best scientist and philosopher of a higher level because he knows the art of putting whole into a part. It's a discovery of modern times, like science it has the power to change the system of society.

When we talk about the origin of novel its roots can be found in English literature. In English literature it is said to be 
a written in $18^{\text {th }}$ century. This genre got popularity and appreciation in $19^{\text {th }}$ century. In this connection Abdul Basit Bhatti writes:

"angrezi adbiyat wich nawel atharwen sadi wich aaya. onwewin sadi wich urooj patus ty jug jahan wich mushhoor thi giya. duniya wich spain dy 'Cervantes' koon pehla nawel nigar munya wendy oondy nawel da naan 'DonQuizot' hy een nawel da angrezi turjuma 1605 wich thiya. (Lashari, 2018, p.8)

But a saraiki writer Hafeez Khan is of the opinion that the very first novel written in 1007 AD is written in Japanese language.

"The Tale of Prince Genji' duniya di kahin ve zuban wich likhya wunjun wala pehla nawel hy jerha qadeem japani zuban wich 'Muraski Shikibu ny 1007 wich likhya ha”. (Shehzad, 2017, p.192)

Saraiki intellectual Dr. Aslam Aziz Durrani in his book (Saraiki Novel Nigari) says about origin of the novel.

“1940 wich ‘Samual Rrichardson’ ny angrezi wich ‘Pamela’ likh karahin nawel nigari di ibtida keti”. (Durrani, 2008, p.17)

After Richordson Henry Fielding, wrote novel ' Joseph Andrew '" in 1742 and took this genre to the peak of perfection. After this a number of writer came in this field like Walterscot, Jane Austin, Charles Dickins, Thackeray, George Elliot, Charlot Bronte, Emily Bronte, Thomes Hardy, Chatterson, H.G. Wells, Gallsworty, Joseph Conred, Henry James, D.H. Lawrence and Virginia Wolf. So all these novelistss took this genre to peak of the success. Beside English novelists, French novelists left no stone unturned in further development of this genre. Among these Elexandre Dumas, Victor Huge, Balzac, Albert, Guy De Maupassant and Russian novelsts like Leo Tolstoy, Maxim Gorky, Anton Chekhove, and Nikolai Gogol have also contributed to development of novel.

In Urdu genre of novel came from English. Deputy Nazeer Ahmed is said to be the first novelist of Urdu language. He put foundation of novel in Urdu by writing masterpiece novel " Mirrat ul Arros " and then this genre got immense popularity. In this connection the name of Abdul Haleem Sharar, Ratan nath Surshar, Mirza Hadi Ruswa are like head among shoulders. The most renowned novelist, Preem Chand took this genre to peak of perfection and he earned his name by writing some masterpieces.

Modernisim affected many genre of Urdu language and a significant number of his contemporaries and successors wrote under his influence. In the genre of novel the effect of Modernisim is prominent. During this time some prominent novelist like, Krishna Chander, Bulwent Singh, Rajindar Singh Bedi, Asmat Chughtai, Aziz Ahmed, Ibrahim Jalees, Ahsan Farooqi etc. played significant role for the development of this genre. Beside these some other writer like Khalid Farooqi, Mustansar Hussain Tarar, Abdullah Hussain, Intizar Hussain, Shoukat Siddiqui, Qurrat ul Aain, Khadija Mastoor are also notworty figures in this connection.

In the beginning saraiki novel took its influence from English novel. As novel came to Urdu from English likewise saraiki novel came from the influence of Urdu novel. In this perspective Qasim Jalal writes:

"Atharwen sudi eesvi wich Engilistan wich nawel likhejun shuroo thiya. Nusri adub di ay dil chekwin sinf angrezi dy wisely naal urdu wich aai hy. Saraiki likharyan dy samny urdu nawlan dy nmony mojod hun. Inhan adub diyan biyan sinfan dy nal nawel nigari dy medan wich aapniyan salahyut dy johr dikhaiy'. (Jalal, 1992, p.79)

There has been a lot of controversy and confusion regarding first novel of saraiki which is still present. Many critics consider Zaffar Lashari's novel " Nazo" as the first novel of saraiki language while some other critics consider Ghulam Hassan Haidrani's novel "Gullo"' as the first saraiki novel. This novel was started being published episode wise since March 1973 in "Mahnama Saraiki Adab Multan "' and this novel was discontinued after its summary was published. It was infact suspense novel and also reflected social issues. 
Dr. Sajjad Haider Perveez gives his views about novel ' Gullo’” of Ghulam Hassan Haidrani.

"beher haal September 1969 wich pehli wari Ghulam Hassan Haidrani dy nawel 'Gullo', kon saraiki risaly hufta war 'Akhtar' Multan ny saraiki zuban da pehla nawel qarar dity bad wich ay nawel may 1973 wich mahwar saraiki adub multan wich chappan shuroo thiya". (Perveez, 1986, p.258)

Dr Hameed Ulfat Malghani writes about the beginning of saraiki novel:

"Jy tuk saraiki adub wic nawel dy mundh badhijun di gaal hy tan 60 dy dahaky wich Ghulam Hassan Haidrani da jasoosi nawel 'Guloo"' dy nan nal likhejun da puta lugy baad wich eenkon Mahnama 'Saraiki Adub "' Multan wich qist waar shaiy kurun da faisla thiya bhul jo hik qist shaiy thevun dy baad doojhi qist wich een nawel da mehz khulasa shaiy kr dita gy. Saraiki wich nawel da mundh Zafar lashari dy nawel "Nazo'"nal budhiya giya". (Malghani, 2003, p.66)

Qasim jalal also presents his views about the beginning of saraiki novel in his book "'Alta'.

“saraiki zuban da pehla nawel "'Guloo"' hy baaz ahdin 'Nazo"' hy”. (Jalal, 1992, p.80)

Nawaz Kawish hold his opinion about the beginning of saraiki novel.

“Kujh danishwaran dy mutabiq saraiki da pehla nawel 'Gullo' hy jerha 1969 wich akhbar 'Akhter' wich qist war chupna shuro thiya per mukumal kahani di sorut wich na chupya”. (Kawish, 1992, p.56).

Hafeez ul Rehman Hafeez express his views in the same connection:

"Saraiki wich nawel nigari bahoon deer naal shuroo thai hy. zamani lihaz naal Ghulam Hassan Haidrani ny 1969 wich pehla nawel 'Gullo' likhya per ay funi tqaziyan ty poora ni utrya 'Gullo' koon hik jasoosi nawelet aakhiya gy. Albta hik saal baad likhya giya Zaffar Lishari da nawel 'Nazo' pehla mukamal saraiki nawul hy”. (Hafeez, 2009, p.21)

Dilshsd Kalanchvi writes about the beginning of saraiki novel:

"Behr haal chupi hovi shukle wich saraiki da jerha pehla nawul sakon lubhdy eenda naan 'Nazo' hy. ay nawul Mehrab Waly dy nengur Zafar Lishari ny likhyay’’. (Kalanchvi, 1987, p.228)

In order to end the controversy and confusion about who was the first novel and novelist of saraiki it is the responsibility of the critics together at the same platefarm and develop a single unanimous opinion so that readers and students may be able to find the right direction in this connection. However, it seems that Zafar Lashari's novel "Naazo" appears to be fulfill the requirement of artistic element and structural technicalities which reaches to the readers with completeness. On the other hand, when it comes to the Ghulam Hassan Haidrani novel 'Gulo' just its summary reached to the readers. However, it was good attempt from Ghulam Hassan Haidrani but credit goes to Zafar Lashari for writing first novel in saraiki language.

\section{A Brief Review of Notable Saraiki Novels}

There are 28 novels are bublished in saraiki language. Given below section gives a brief review of each of these in a way that may help understand the relationship of Saraiki novel with the sociocultural context of Saraiki community.

The novel "Gullo"' was started being published in weekly news paper " Akhtar' but could not be published in the farm of complete story. This novel "Gullo" is written by Ghulam Hassan Haidrani. After sometimes some episode of this novel were published in 1971 in Mahnama Saraiki Adab Multan but after publishing its summary it was not published any more.

Dr. Sajjad Haider Perveez writes about it: 
"Yeh aik jasoosi nawelet tha. Is nawelet ki mehz tulkhees bht baad main 1973 main mahnama saraiki adub Multan main shai ho ski"' (Perveez, 1986, p.149)

In this novel not only suspense but glimpsis of social problems and culture are also shown. In this way when we compare both the novels, the novel "Nazo" written by Zaffar Lashari's seems to be the first novel of saraiki novels which was published by 'Saraiki Adbi Majlis' in 1971. It appeard in complete book form while the novel 'Gulo' could not appear in book form

According to Nawaz Kawish:

“Ay nawelit baqaida kitabi shukl wich asady samny ni aaya lihaza eenkon saraiki da pehla nawul ni aakh sugdy". (Kawish, 1992, p.57)

The first ever novel which was published in complete is "Nazoo' by Zaffar Lashari. This novel was published by 'Saraiki Adbi Majlis Bahawalpur' in 1971. On the front cover of this book it is also written that it is the first saraiki novel. Many critics and intellectuals present their arguments that this is the first saraiki novel.

Dr. Sajjad Haider express his opinion that this first novel.

'Nawul 'Nazo' baqaida nawul hy ty chupi sorut wich pehly samny aaiy tahoon kujh doost eenkon saraiki da pehla nawul aahdin'. (Perveez, 1986, p.259)

Dr Hameed ulfat malghani writes:

“Saraiki zuban wich nawul da mundh Zafar Lishari dy nawul 'Nazo’ nal budhiya giya'. Malghani, 2003, p.66)

Qudsiya Qasim argues in the favor of this novel:

"Zafar Lishari saraiki da pehla likhari hy jain nawul likhyay inhan da nawul ' Nazo ' saraiki da sub ton pehla nawul tusleem keta gy'. (Durrani, 2008, p.88).

This novel has been included in the syllabus of M.A. Punjabi in Punjab University. Consisting of 368 pages 'this novel has been written in the background of India and Pakistan devided into two separate countries. Its main subject matters are issues caused by division and end of human relations, human behavior and passions. When subcontinent was devided into two parts there came a big revolution and this revolution cast effects on a number of writer and Zaffar Lashari also written this novel "Nazo" in that scenario. In this novel we meet twelve representative characters. The herion of this novel is an innocent Hindu girl whose name is Nazo and Akhtar is the hero of this novel. The plot of this novel is strong and the characters are lively. We also see sequence of event here.

The second novel which was published in saraiki is "'Apni Rut Jo Panri Thai'" which was published by saraiki adbi majlis in 1972. This novel consists of just 80 pages and that's why it is named as novelette rather than novel. The writer of this novel is Dr. Muneer Alvi. This novel laments the miserable plight of the people in which ruthlessness of human beings has been treated as subjecy matter and it is also told here that whenever man has to counter unfavorable situation he will have to lookforwerd with positivity. The style of this novel is non-tradional.

Dr Muneer Alvi himself writes about this novel:

“Main eendy wich oo sub kujh likhyay jo kujh thenda py”. (Kalanchvi, 1987, p.229)

About the character and style of this novel Qasim Jalal writes:

"Een mukhtasir nawul koon Dr Alvi horan wudi mohabut nal likhyay sary kirdar miyari hin purhun waly koon ay 
bhurwan ihsas thendy jo waseeb wich kiwain buraiyan khindiyan hoyan hin. Asloob sada ty taseer nal bhurya hoya hy aty lehja miyari wurtyndy'. (Jalal, 1992, p.81)

Ghulam Nabi is the hero of this novel. Khuda Baksh his elder brother who brought him up after the death of his father and got him educated. The prominent characters of this novel are Ghulam Nabi, Khuda Baksh, Raziya, Hashim and Jewan. In this novel it is shown that how a brothers turns out to be enemy of his own brother.

The novel 'choliyan" written by Mohammad Ismail Ahmadani was publish by "'Sangat Publications in 1983. This novel is a beautiful addition to saraiki literature. It can be said that this novel is upto the artistic intellectual standards. We can match it even to novel of international standard.

Dr Aslam Aziz Durrani writes about its standard as follows.

"Saraiki wich ajun tain swaiy Ismail Ahmedani dy nawul 'choliyan' toon elawa kai umda ty wuda nawul samny ni aaya". (Durrani, 2008, p.74)

The style of this novel is different from the rest of the novels of Saraiki language. In this novel the writer himself is speaker as we find him engaged in conversation with self and symbolic style has been adopted here. In this novel writer has passed through different stages in a big single step and has brought saraiki novel to a new destination, Ismail Ahmdani is the first writer who introduced symbolism as is expressed by Nawaz Kawish.

"Nusri adub wich alamut da istamal aokha kum hy saraiki nawul wich alamut kon shuroo karun waly Ismail Ahmadani hin. Aapny tarekhi virsy koon golun wasty Ismail Ahmadani ny khud kalami nal tareekh koon ikaiyan wich tuqseem kur ky aapni gal wazeh keti hy’’. (Kawish, 1992, p.58)

Dilshad Kalanchvi writes about the novel choliyan:

"Eendy wich aap nal aap galhin karun dy punj chi baab vi shamil hin. Nuzriyati tour ty een nawul koon islami ni aakhya wunj sageenda kun jo eendy wich hindu mithalogy aty culture hy’. (Kalanchvi, 1987, p.231)

Qasim Jalal writes:

"Een nawul wich alamti andaz ikhtiyar keta gy. ay nawal dy aam osolan dy mutabiq ni likhya giya een sangoo ay munfarid andaz rakhendy', (Jalal, 1992, p.81)

Dr Hameed Ulfut Malghani is of the opinion:

"Ay nawul aam riwayti andaz toon hut ky likhya gy jendy wich saraiki waseeb dy kai musly kuthy kur dity gyn". (Malghani, 2003, p.68)

The second novel of Zafar Lashari which name is "Pahaj" was published by Pakistan Punjabi Adbi Board Lahore in 1983. Before that this novel was being published in Saraiki magazine "Saraiki Adab" episode wise. In this novel Zafar Lashari has highlighted many social issues like economic, physchological and cultural issues. The dominant characters of this novel are Raheema, Nazar, Sanwal, Ghazala, Bhoral and Zareena. This novel consists of both rural and urban characters.

Nawaz kawish writes about this novel of Zafar Lashari.

“Saraiki adub agr kahin nawul ty fakhar ya man kr sgdy tan oo sain Zafar Lashari da nawul 'Pahaj' hy”. (Kawish, 1992, p.58) 
Qasim Jalal talks about the subject matter of this novel:

"Pahaj wich asady waseeb dy hik haan saar ty dukhaly musly koon mouzo bnaya gy asakon eendy wich andrly juzbat ty fitrut dy munzran tusweran mildiyen'. (Jalal, 1992, p.81)

This novel was republished by Jhoke Publishers Multan in 2019 under the observation of Basit Bhatti.

'Ammar kahani' is the second novel from the pen of Mohammad Ismail Ahmadani which was published by Saraiki Publicationars Rasoolpur in 1988. This novel from beginning to end continues to reflect saraiki thinking and history of Saraiki literature. It means history of Saraiki literature has been compiled and arranged.

Dr Sajjad Haider Perveez writes:

“Ay nawul saraiki fikr o adub di tarekh di dustaweez hy”. (Perveez, S. H. (1986, p.152)

Ammar Kahani is new experience in a Saraiki novel. This experiment has been proved fruitful enough to demonstrate his skills in the art of novel writing.

Aslam Rasoolpuri writes in his book:

'Een nawul koon Ahmadani sahib 'A literary history saga' ahdin ty saraiki di fikri adbi tehreek di dastaweez qarar dendin’. (Rasoolpuri, 2009, p.145)

In this novel the writer has told story of the revival of Saraiki movement and evolution and his purpose was to give awareness. Through his positive style and bent of mind he has taken Saraiki novel to a respectable place

The novel 'Sanwal' written by Fiaz Hussain Qasir Fareedi was published through Sanwal Saraiki Adbi Academy Dera Shamas. The beauty of this novel is that it reflects Saraiki culture and society in a vivid manner. The coustoms and tradations of marriage and funeral are part of this novel. This novel has got a documentary from as it shows local culture like dance, moments of happiness and a contrast of village and city life has also been beautifully described. Beside that we get a massage of sacrifiece for others and selflessness.

Dr Sajjad Haider write regarding that novel:

“Qasir Fareedi ky nawul 'sanwul' main bataya gya hy keh qiyam e Pakistan ky wqt hijrut kr ky aany walon ky sath saraiki logon ny insar-e-Madinah ka sa burtao kiya’’. (Perveez, S. H. (1986, p.153)

Qasim Jalal write about this novel of Fiaz Hussain:

"Fiaz Hussain Qasir Faredi horan dy nawul 'Sanwul' wich saraiki waseeb di saqafut da bhurwan andaz pesh kita gy. Saraiki dy theth lufzan da wrtawa ty likht di sadgi eendy sunhup koon wadha dity mujmoi tour ty ay hik kamyab tajurba hy'. (Jalal, 1992, p.82)

In this novel the novelist speaks in a simple tone and this adds to the purity of his experience.

The novel "Sary Sugan Sohagray" written by Dilshad kalanchvi was published through "Academi Saraiki Adab" in 1991. Dilshad kalanchvi is the one of the pioneers of saraiki writers. This novel consists of 43 chapters and every chapter has been named differently. This novel reflects the social norms of the locality. The simple culture of Cholistan has also been portrayed in this novel and customs and traditions of saraiki area have also been touched upon.

Dr Hameed Ulfat Malghani says regarding this novel: 
"Dilshad Kalanchvi dy nawul 'Saray Sugan Sohagray koon saraiki zuban da turbiya nawul wi aakhiya wunj sagendy jendy wich rohi cholistan di saqafut koon bhurween andaz nal pesh kita gy. Een nawul wic moashry dy kai rung een trha wazeh thain pora mahool wazeh thi gy'. (Malghani, 2003, p.68)

There are 22 characters in this novel and it's a lengthy novel. The characterization and way of expressions of the write is up to the mark and this adds to the beauty of the novel.

Shoukat Mughal writes in this connection.

"Nawul nigar ka asloob umda hy. onhon ny zuban o biyan per khasosi tawja di hy agrchy in ki tehrer main la shaoori tour per urdu ky by shumar alfaz aay hain laiken shaori tour per saraiki ky by shumar theth aur khalis alfaz trakib aur mohawry bhi istimal kiyay hain is main sraiki kahawtin istimal hain jo saraiki ka asasa hain'. (Mughal, 2015, p.159)

The novel 'Bhag Suhag' is written by Rahi Gabool which was published through "Sanwal Saraiki Sangat RahimYar khan" in 1994. This novel shows political and social issues of people of present times. In this novel the accounts of political parties are also given who makes false promises to the people during election campaigns and after winning elections they don't fulfill their promises. The student politics is also shown in this novel.

Dr Aslam Aziz Durrani expresses his views:

"Een nawul wich hik tasawurati riyasut ka nuqsha pesh keta gy. Jithan zalim jageerdar ty surmaya dar wusdin". (Durrani, 2008, p.148)

Dr Sajjad Haider Perveez writes about it:

“Rahi Gabool ka nawul 'Bhag Suhag' romanvi hony ky sath islahi bhi hy'. (Perveez, S. H. (1986, p.153)

The novel "Sanwal Moor Moharan" written by Iqbal Bano published from "Lungriyal Publishers Vehari” in 1997. Earlier on, his novel had been published episode wise from Saraiki Adab Multan in 1985-86. This is the first ever novel which came from the pen of a woman. This novel revolves around social issues as the tussle between farmers regarding land disputes and the cruelty and mistreatment on the part of step mothers.

Dr Aslam Aziz durrani writes in this way:

"Sanwul Moor Moharan 'saraiki wich kahin tremit likhari da pehla nawul hy ay hik moashrty nawul hy jindy wich aouratiyat da ansur bahon numayan hy', (Durrani, 2008, p.155)

Dr Hameed Ulfat Malghani says about this novel:

"Iqbal bano dy nawul 'sanwul moor moharan 'kon trimt adb da pehla nawul aakhiya wunj sagendy jendy wich pati wunjun wali pet preet di kahani wich dehat da mahool pahaj da kirdar. balen di khawish ty jagerdari nizam dy bary aty murd di hakmiyat da jenda jagda sabot pesh kita gy'. (Malghani, 2003, p.69)

The novel "Jhokan Thesin Aabad Wull " written by Jamshed kalanchvi is social novel which was published from "Akademi Saraiki Adab Bahawalpur" in 2002. The atmosphere of this novel is enriched. The characterization of this novel is highly impressive. About the subjects of this novel

Dr Hameed Ulfat writes:

'Nawul' Jhokan Thesin Aabad Wull' wasebi hawalen kon nishabur krendy jendy wich rohi dy munzur dehati ty shehri 
zidgi da frq ty ay denh pesh aawun walyan musliyan koon mouzo bnaya gy’. (Malghani, 2003, p.70)

Dr Asslam durrani writes about the characterization of this novel:

"Kirdar nigari vi khoob hy. kirdar flat ty yuk rukhy ni. Kirdaren dy under irtqai unsure mojod hy". (Durrani, 2008, p.161)

In this novel courage and hard work have been highlighted.

The novel 'Beri Wich Dariya' written by Aslam Ansari was published by 'Lok Reet Publishers Multan' in 2002. Consisting of 223 pages this novel occupies a unique palace on the horizon of Saraiki literature. The structure of this novel has been fabricated around the saraiki belt. Both village and city life are described here. According to the writer of this novel the pure and typical Saraiki language has been used here. The plot of this novel is strong. Some aspects of characterization are too good. Sanwal is central character of this novel. He loves humanity.

Hafeez ul Rehman Hafeez express his view point about this novel.

"Beri Wich Duriya' dy kirdar saraiki waseeb khas tour ty Multan di tehzeeb riwayut dy sanchy wich dhuliyay hoy hin. kujh tan afsanvi kirdar hint y kujh haqeqi ty tarekhi’. (Hafeez, 2009, p.25)

Dr Aslam aziz durrani writes about this novel:

"Mujmoi tour ty ay nawul saraiki nawul di tarekh wich ahm maqam rakhendy apny asloob muqalma nigari, majra nawesi, wurtawy di wja ton saraiki nawul nigari wich eendi ahmiyut kahin turhawin ni ghtdi'”. (Durrani, 2008, p.170)

The novel "Mehroo" which came from the pen of Iqbal Hussain Bhapla was published through "Shoukat Bhapla Academy Multan" in 2002. This novel comprises 102 pages. In this novel the romantic love between a young man and bagger gipsy woman is depicted. To some extent this novel has been given touch of poetic elements and proverbs and idioms have been used artistically. The main characters of this novel are Bala Jogi, Mehroo and Sawan Faqeer are head among shoulder.

The novel "Konj" has come from Rahi Gabool. The story of this novel is about a village girl having less education. Her purposal of marriage is rejected by his fiancé. The beginning of this novel takes place from village and the later part of the novel takes us to the city life. This novel shows the social issues which result from childhood engagements.

Shoukat Mughal writes about this novel:

'Koonj' Rahi Gabool da nawul hy jenkon inhan ny saraiki waseeb dy pich dith wich likhyay. Nawul dam ouzo waseebi hy Saraiki waseeb wich niky la diyan shadiyan dy gandhy wudy la wich gul dy gulanwen bun wendin. Saraiki waseeb vi eeho jhain musliyan nal trut bhun da shikar thendy ay nawul aenjhy musly koon sady samny ghin aandy'. (Mughal, 2015, p.163)

The novel 'Sajan Dushman' is written by Rahi Gabool. It was published from "Gabool Saraiki Taleemi Idara Bhong Shareef". On its front cover we can see that it is social and reformative novel. The land disputes and family conflicts have been portrayed. The characters of this novel are people of this earth as they hanker after wordly andmaterial things.

The novel 'Phoog' has come from Kashif Baloch. It was published fron "Kitab Nagar Multan" in 2006. It is the lengthiest novel of Saraiki language so far consisting of 480 pages. The style of this novel shows bold characters.

Dr Aslam Aziz Durrani in his book 'Saraiki Novel Nigari’ gives his opinion about this novel:

"Bahoon afsoos nal aakhna pondy keh een nawul kon purhun dy baad mehsoos thendy keh ay hik bimar zehn di bemar 
tukhliq hy nawul da sir hy na peer na ay mith hy na ay fintacy hy”. (Durrani, 2008, p.175)

Hafeez khan writes about the same novel:

“Angrezi dy ustad 'Kashif Baloch' ny saraiki dy ishq wich an sonhy aslob kon wuth krahin nawul phoog likh sutyay. Bhanwen jo ay nawul aapny kraft dy hisab nal heran kun hy per eendy wich wurti zuban kon nngech da menrha dy krahin eenkon purhyay bina eendi tufhem dy jundry maar dity gen'. (Shehzad, 2017, p.193)

The novel 'Basantee'" is written by Iqbal Hassan Bhupla. It was published from Saraiki Research Centre BZU Multan in 2006. The story of this novel consists of 96 pages. It's better to call it novelette rather than a novel. This romantic love story is about two characters a young land lord Malik Lajpal and gipsy woman Basantee. This story seems to happen outside reality. This story does not reflect to culture of the people of this land.

Dr Aslam Aziz Durrani writes:

"Main een rai toon itna ikhtilaf zaroor karesan keh 'Basuntee' saraiki dhrti di tehzeeb ty kulchur da numainda nawul hy". (Durrani, 2008, p.180)

Aslam Rasoolpuri says about this novel in his book:

"Kahani wich dehati zumindarana zindagi ty moashry di akasi nuzar zaroor andi hy ewin pukhi wasen di zindagi ty riwayat wghyra bary vi ilm thendy'”. (Rasoolpuri, 2009, p.446)

The novel 'Mujrim' is the first attempt of Aown Mohammad Kalanchvi. It would be better to call it novelette rather than a novel because it consists of only 32 pages. It was published from Saraiki Adab Bahawalpur in 2007. It is suspense novelette. It is a successful attempt of writer.

The novel 'Purdees na wunj' is from Rahi Gabool. It was published from "Gabool Saraiki Taleemi Idara Bhong Shareef Rahim Yar khan" in 2008. It consists of 157 pages. Social issues are vividly described in this novel. Exploitation by a step mother and village and city life is also shown. The characters of this novel look like movie characters and it seems that they are away from real life.

'Manik laal' is novel written by Iqbal Hassan Bhupla. It was published from "Shoukat Bhupla Adbi Academy" in 2007. It consists of 84 pages In this novelette the events related to division of India have been presented. A social evil kidnapping children is highlighted also. Story of this novel contains suspense but this story seems to be away from reality. Some characters of this story are too week as Aslam Aziz Durrani wraites:

"Een nawul di kirdar nigari kumzoor hy. nawul da hero jendy naan ty nawul da naan Manink Laal rukhiya gy. Ay hik ghurya ghraya kirdar lgdy”'. (Durrani, 2008, p.183)

Habib Mohana is the writer of this novel “Allah Lahesi Monjhan”. It was published in 2010.

This novel perfectly depicts our society. In this novel hunger of society has been highlighted and low standard of people have been shown. Ways of living of peole and economy have been narrated with a mature outlook of the writer.

The novel 'Ghanr' has been written by Saleem Shehzad. It beautifully covers social issues of the people. This novel has highlighted the issues which an under-developing country faces for example the issue of terrorism has been discussed. The wide spread unemployment has also been highlighted along with energy crises. Beside that we see that how epidemic and pendamic affect the people in rapidly changing global world.

The novel 'Nit Kurlaway Koonj' is written by Hafeez Gillani. It was published from 'Jhok' Publishers Multan in 2012. The story of this novel revolves around a village Koh e Suleman where there is hunger, powerty and thirst. In fact, this 
story laments the hard life conditions and sense of deprivation of this entire area. The ways of living of the people of Koh e Suleman are different as compared with other parts of the area.

'Pandhi' is novel by Ashraf Javeed Malik. It was published by Jhok Publishers Multan in 2013. This novel covers development of many thousand years. Effort has been made to highlight the older period of human history especially ancient history, culture and civilization of Multan.

'Dildar Sadqay' is a novel written by Rahi Gabool in which we come across political and social aspects. This novel has been written to spread light of knowledge. There are thre main characters in this novel. The entire story moves around these characters. This novel tells us the advantages and benefits of being united.

The novel 'Khari Dendi Haan Sanerha' is written by Habib Mohana. This is a social novel. In which woman of society is highlighted. This novel is published by Daman publishers in 2016.

'Paloota' is a novel by Saleem Shehzad. It was published by Multan Institute of Policy and Research Multan. This novel brings to lime light the issues which a country faces and besides that conspiracies of enemies have been highlighted that how enemy creates enmity between citizens of a country. The enemy tries to make people fight on the basis of race, language and religion. It is best social novel. In this novel we see some things about saraiki language. This novel is symbolic one.

The novel 'Adh Adhory Lok' is masterpiece of Hafeez Khan in which the issue during creation of Pakistan and after Pakistan was established have been highlighted. Here we see issues faced by state Bahawalpur at social and political level. Anti one-unit movement against one unit is highlighted. It shows the exploitation of the people on the basis of one unit. This novel has four characters and strong plot and meture characterization.

In the history of saraiki there have been published such four novels which were translated from other language to saraiki language as we see that in 1977 a novel "Touba Zaari" was published from "Saraiki Adbi Majlis Bahawalpur" which was translated by Dilshad Kalanchvi. In 1979 a novel 'Firdos Thigali' was published from 'Saraiki Adbi mMajlis Bahawalpur' translated by Brigadier Nazeer Ali. Yet another novel 'Qissy ty Pir Qissa' published from 'Saraiki Adbi Majlis Bahawalpur” in 1976 translated by Dilshad Kalanchvi. In 1985 a novel 'Ishq Day Wanrj Anokhy' was published by Saraiki Adbi Tehreeq Multan and Sajjad Haider Perveez was the translator of this novel.

\section{Conclusion}

The paper highlights the historical evolution of the literary genere 'novel' in Saraiki language and literature. The paper also relates this historical evolution with the sociocultural context and dynamics of Saraiki community. A brief review of important Saraiki novels has been presented. The discussion offers the research scholars in the area of Saraiki language and literature important insights about growth and development of novel in Saraiki literature.

\section{References}

Kalanchvi, D. (1987). Saraiki Zuban Ty Adub. Saraiki Adbi Mujlis, Bahawalpur, Pakistan

Hussaini, A. A. (1990). Novel Aur Novel Niga. Karwan e Adub, Multan, Pakistan

Kalancvi, D. (1982). Saraiki aur is ki nusur, Saraiki. Adbi Mujlis, Bahawalpur, Pakistan

Hussaini, A. A. (1951). Novel ki tunqeedi tareef, Urdu Academy, Lahore, Pakistan

Lashari, Z. (2018). Pahaj, Jhoke Publishers, Multan, Pakistan

Durrani, A. A. (2008). Saraiki novel nigari. Saraiki Adbi Board, Multan, Pakistan

Hafeez, H. R. (2009). Saraiki nuqd adub. Saraiki adbi board, Multan, Pakistan

Shehzad, S. (2017). Paloota. Multan institute of policy and research, Multan, Pakistan

Durrani, A. A. (2008). Saraiki novel nigari. Saraiki Adbi Board, Multan, Pakistan

Jalal, Q. (1992). Alta. Idara tamer fikir, Bahawalpur, Pakistan

Perveez, S. H. (1986). Saraiki adub di mukhtasir tareekh. Saraiki publicashnors, Muzaffar Garh, Pakistan

Malghani, H. U. (2003). Likhat ty likhari. Saraiki adbi board, Multan, Pakistan

Kawish, N. (1992). Turka. Saraiki adbi mujlis, Bahawalpur, Pakistan 
Hafeez, H. R. (2009). Saraiki nuqd adub. Saraiki adbi board, Multan, Pakistan

Perveez, S. H. (1986). Saraiki zuban o adub ki mukhtasir tareekh. Muqtudra qoumi zuban, Pakistan Rasoolpuri, M. A. (2009). Nitary. Saraiki adbi board, Multan, Pakistan

Mughal, S. 2015). Dilshad kalanchvi Shuksiyut aur fun 